\title{
Measurements of carbon dioxide and heat fluxes during monsoon-2011 season over rural site of India by eddy covariance technique
}

\author{
M N Patil*, T Dharmaraj, R T Waghmare, T V Prabha and J R Kulkarni \\ Indian Institute of Tropical Meteorology, Dr Homi Bhabha Road, Pune 411 008, India. \\ ${ }^{*}$ Corresponding author.e-mail: patil@tropmet.res.in
}

An increase in carbon dioxide $\left(\mathrm{CO}_{2}\right)$ concentrations in the atmosphere due to anthropogenic activities is responsible for global warming and hence in recent years, $\mathrm{CO}_{2}$ measurement network has expanded globally. In the monsoon season (July-September) of year 2011, we carried out measurements of $\mathrm{CO}_{2}$ and water vapour $\left(\mathrm{H}_{2} \mathrm{O}\right)$ concentrations along with wind and air temperature over a tropical site in southeast India having rural topography. To collect these observations, the instrumentations used were the sonic anemometer for wind and temperature, and the open path $\mathrm{H}_{2} \mathrm{O} / \mathrm{CO}_{2}$ infrared gas analyzer for $\mathrm{CO}_{2}$ and $\mathrm{H}_{2} \mathrm{O}$ concentrations. Using these observations, we explored the diurnal variability of $\mathrm{CO}_{2}$ flux along with sensible and latent heat. The $\mathrm{CO}_{2}$ flux was positive during night-time and negative during daytime and in phase with convective instability. The $\mathrm{CO}_{2}$ flux relationships with the meteorological parameters such as wind speed, temperature and heat fluxes have been analysed. The seasonal (monsoon) half hour mean of $\mathrm{CO}_{2}$ flux which was $-3.55 \mu \mathrm{mol} \mathrm{m}{ }^{-2} \mathrm{~s}^{-1}$ indicated the experimental site as a $\mathrm{CO}_{2}$ sink region (net seasonal uptake). An increase in $\mathrm{CO}_{2}$ concentrations during weekends was not observed due to unavailability of heavy vehicular traffic.

\section{Introduction}

The increased concentration of greenhouse gases (GHGs), including carbon dioxide $\left(\mathrm{CO}_{2}\right)$, in the atmosphere due to anthropogenic activities is responsible for global climate change and increases in the intensity and frequency of extreme weather events (IPCC 2007). Due to the significant increase in atmospheric $\mathrm{CO}_{2}$ over the last few decades (Keeling et al. 1995; Artuso et al. 2009), exchange of $\mathrm{CO}_{2}$ between the atmosphere and the biosphere and oceans has become a major focus of research through its measurements by different techniques. In the recent study (Artuso et al. 2009), the $\mathrm{CO}_{2}$ concentration showed a linear growth of

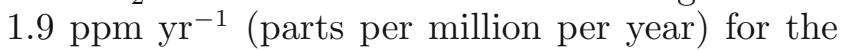

years from 1992 to 2008. Human activities such as fossil fuel emissions, cement production, and land use changes contributed to the noteworthy increase of atmospheric $\mathrm{CO}_{2}$. The changes in land use, determined a considerable reduction of $\mathrm{CO}_{2}$ uptake capacity by plants, which amplified the general global increasing trend. The available global $\mathrm{CO}_{2}$ records are used for predicting its future trend and for planning international policy strategy for its reduction. In order to validate the inventory data, independent methods based on atmospheric measurements have been suggested recently (Gibert et al. 2007; Casso-Torralba et al. 2008; van der Laan et al. 2009; Worthy et al. 2009).

Many studies from tropical region (Brummer et al. 2008; Lohou et al. 2010) and mid-latitudinal

Keywords. Carbon dioxide flux; eddy covariance; heat fluxes; meteorological parameters; monsoon. 
region (Lee and $\mathrm{Hu}$ 2002; Pawlak et al. 2011; Barr et al. 2012) depicted intra seasonal and annual characteristics of $\mathrm{CO}_{2}$ fluxes over different land surfaces. The urban area acted as a source for $\mathrm{CO}_{2}$ (Song and Wang 2012). There are very few studies available from the Indian subcontinental region (Dharmaraj et al. 2012). The presented results are the first of $\mathrm{CO}_{2}$ measurement at the site of south-east India, and one of the very few by eddy covariance technique. The aim of this work is to quantify the $\mathrm{CO}_{2}$ concentrations and fluxes in rural area of south-east region of India. The $\mathrm{CO}_{2}$ observations are analyzed in terms of its diurnal variability with the progress of monsoon. The correlations of $\mathrm{CO}_{2}$ flux with meteorological parameters have been proposed. The analysis presented in this study could be helpful to improve how the rural regions of Indian subcontinent are to be incorporated in the air quality and climate models.

\section{Experimental site and instrumentation}

The Eddy Covariance (EC) system was installed over a station Mahabubnagar $\left(16.44^{\circ} \mathrm{N}, 77.59^{\circ} \mathrm{E}\right.$, $498 \mathrm{~m}$ a.s.l.) in south-east India in the monsoon period of 2011 as a part Cloud Aerosol Interaction and Precipitation Enhancement Experiment - Integrated Ground Observations Campaign (CAIPEEX-IGOC). The measurement site is on the outskirts of the city at a distance of $\sim 15 \mathrm{~km}$, with rural characteristics. The population of the Mahabubnagar city is $\sim 0.158$ million and no significant industrial activities are found near the site. Coal, gas and oil consumed for communal and transport purposes generate the main flux of anthropogenic $\mathrm{CO}_{2}$ within the region. No thermal plant or cement factory is located in the Mahabubnagar district. Thus, strong anthropogenic sources of $\mathrm{CO}_{2}$ are absent in the immediate vicinity of the measurement site. The vehicular traffic was low with about 10 vehicles passing in one hour. The railway track was at a distance of about $0.5 \mathrm{~km}$ in the south with low traffic. The railway route was unelectrified and consumed diesel. One rice mill (unoperational in monsoon) was available at a distance of $1 \mathrm{~km}$ in the north. In the surrounding area, people used wood and kerosene for cooking purpose. The Mahabubnagar city, which is the district headquarters is about $15 \mathrm{~km}$ away from the experimental site. A small residential locality with 1520 huts was in the south-west direction at about $0.7 \mathrm{~km}$. A water reservoir, Koilpatti, existed at a distance of about $30 \mathrm{~km}$ in the south-west. Thus, the contributors for $\mathrm{CO}_{2}$ production were partially from vehicular and domestic cooking, agricultural practice, etc. The slope of the site was horizontal, one hill ( $\sim 800 \mathrm{~m}$ high) was located at about $2 \mathrm{~km}$ in the west. Towards west and north, at a distance of about $100 \mathrm{~m}$, thorny plants with a height of about $1 \mathrm{~m}$ were available. Towards east and south, at a distance of about $100 \mathrm{~m}$, paddy crop was available with a height of $0.2 \mathrm{~m}$ in the month of August which increased to about $0.80 \mathrm{~m}$ in September.

The EC system consisted of the $\mathrm{CO}_{2} / \mathrm{H}_{2} \mathrm{O}$ open path gas analyzer (Model LI-7500A by Licor Inc.) integrated with 3D sonic anemometer (Model wind master Pro by Gill Instruments). The distance between the sonic anemometer and $\mathrm{CO}_{2} / \mathrm{H}_{2} \mathrm{O}$ analyzer was about $20 \mathrm{~cm}$ (figure 1 ). The wind and temperature as well as $\mathrm{CO}_{2}$ and $\mathrm{H}_{2} \mathrm{O}$ observations

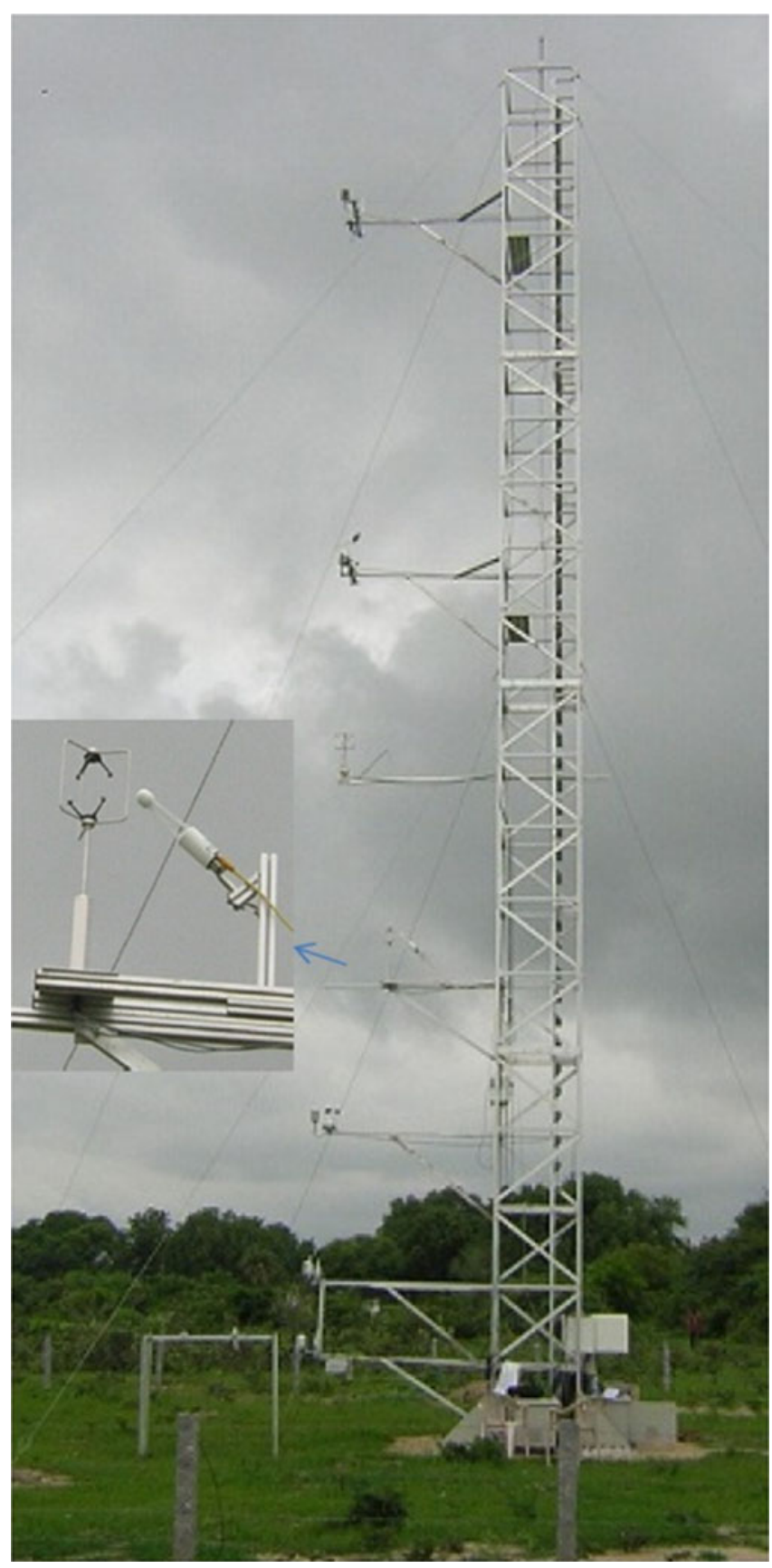

Figure 1. Location of the observational site. 
were sampled at $10 \mathrm{~Hz}$. Since both the sensors were part of the EC system, and were integrated to single data logger (LICOR), there was no time-lag in measurement by both the sensors. The complete description of both the sensors is given in table 1 .
The EC sensors were mounted on $20 \mathrm{~m}$ mast as shown in figure 1 . The EC observations were taken at $8 \mathrm{~m}$ height upto August 4, 2011 and later, the system was shifted to $6 \mathrm{~m}$ height to make provision for other measurements at $8 \mathrm{~m}$. The precipitation

Table 1. Specification of eddy covariance system installed during CAIPEEX-IGOC.

$\mathrm{CO}_{2} / \mathrm{H}_{2} \mathrm{O}$ gas analyzer-Model LI-7500A

\section{Type}

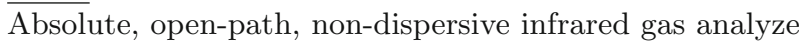

\section{Detector}

Thermo-electrically cooled lead selenide

\section{Output rate}

$\overline{5,10 \text {, or } 20 \mathrm{~Hz}}$, software selectable

Path length

$12.5 \mathrm{~cm}$

Calibration range

For $\mathrm{CO}_{2}$ : 0-3000 ppm

For $\mathrm{H}_{2} \mathrm{O}$ : 0-60 ppt

Accuracy

For $\mathrm{CO}_{2}$ : within $1 \%$ of reading

For $\mathrm{H}_{2} \mathrm{O}$ : within $2 \%$ of reading

Zero drift (per ${ }^{\circ} \mathrm{C}$ )

For $\mathrm{CO}_{2}$ : $\pm 0.1 \mathrm{ppm}$ typical; $\pm 0.3 \mathrm{ppm} \max$.

For $\mathrm{H}_{2} \mathrm{O}$ : \pm 0.03 ppt typical; \pm 0.05 ppt max.
3D Sonic anemometer-Model WindPro

\section{Outputs}

Output rate: $1,2,4,8,10,16,20,32 \mathrm{~Hz}$

Sample rate (automatically selected): 20 or $32 \mathrm{~Hz}$

Units of measure: $\mathrm{m} / \mathrm{s}, \mathrm{mph}, \mathrm{KPH}$, knots, $\mathrm{ft} / \mathrm{min}$

Averaging : Flexible 0-3600 s

\section{Wind speed}

Range : 0-65 m/s

Resolution : 0.01 or $0.001 \mathrm{~m} / \mathrm{s}$

Accuracy $(12 \mathrm{~m} / \mathrm{s})$ (Standard)* $:<1.5 \%$ RMS

Accuracy $(12 \mathrm{~m} / \mathrm{s})$ (to special order)* $\#:<1.0 \%$ RMS

\section{Wind direction}

Range: 0-359.9

Resolution : 1 or 0.1

Accuracy $(12 \mathrm{~m} / \mathrm{s})$ (Standard)* $: 2$

Accuracy $(12 \mathrm{~m} / \mathrm{s})$ (to special order)* \# $: 0.5$

\section{Speed of sound}

Range : $300-370 \mathrm{~m} / \mathrm{s}$

Resolution : $0.01 \mathrm{~m} / \mathrm{s}$

Accuracy : $< \pm 0.5 \% @ 20^{\circ} \mathrm{C}$

Sonic temperature range: $-40^{\circ} \mathrm{C}$ to $+70^{\circ} \mathrm{C}$

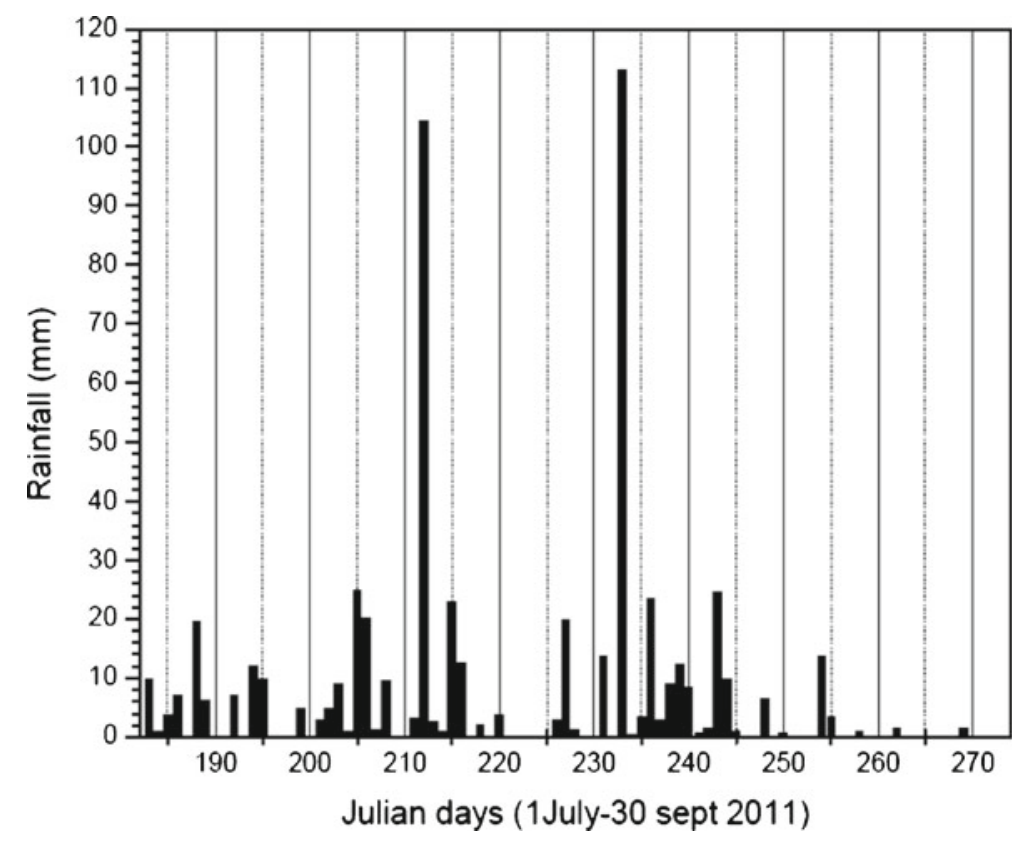

Figure 2. Rainfall recorded over Mahabubnagar during July 1 to September 30, 2011. 
recorded during the period of observations is shown in figure 2 .

\section{Estimation of fluxes}

The sonic anemometer measured the longitudinal $(u)$, lateral $(v)$ and vertical $(w)$ components of wind and virtual air temperature, where as the LICOR $\mathrm{CO}_{2} / \mathrm{H}_{2} \mathrm{O}$ analyser system measured the $\mathrm{CO}_{2}$ and water vapour concentrations (water vapour mixing ratio- $q$ ). The fluctuating components of $u, v, w, \theta, q$ and $\rho \mathrm{CO}_{2}$ are derived using following equations.

$$
\begin{gathered}
u^{\prime}=u-\bar{u}, \\
v^{\prime}=v-\bar{v}, \\
w^{\prime}=w-\bar{w}, \\
\theta^{\prime}=\theta-\bar{\theta} \\
q^{\prime}=q-\bar{q}, \\
\rho \mathrm{CO}_{2}^{\prime}=\rho \mathrm{CO}_{2}-\overline{\rho \mathrm{CO}_{2}} .
\end{gathered}
$$

The primes represent the fluctuations and over-bar the averages over the period of 30 minutes. Initially, we removed the observations that were made during the rainy hours. The natural wind coordinates were rotated for minimizing the effect of vibrations and deviation of the sensors according to Lee et al. (2004). Later, the fluxes were estimated using the following relations:

$$
\begin{gathered}
\mathrm{FCO}_{2}=\overline{w^{\prime} \cdot \rho \mathrm{CO}_{2}^{\prime}} \\
\mathrm{H}=\rho \operatorname{Cp} \overline{\theta^{\prime} w^{\prime}} \\
\mathrm{LE}=\rho \operatorname{Lv} \overline{q^{\prime} w^{\prime}} \\
u_{*}=\left[\left(\overline{u^{\prime} w^{\prime}}\right)^{2}+\left(\overline{v^{\prime} w^{\prime}}\right)^{2}\right]^{\frac{1}{4}}
\end{gathered}
$$

where $\mathrm{FCO}_{2}, \mathrm{H}$, LE are the fluxes of $\mathrm{CO}_{2}$, sensible heat and latent heat, respectively, $u_{*}$ is the friction velocity. $\rho$ is the air density, $\mathrm{Cp}$ the specific heat at constant pressure and $\mathrm{Lv}$ is the latent heat of vapourization. The observations collected at $10 \mathrm{~Hz}$ for 30 minute durations were stored in a single data file which consisted of 18,000 sample points. Each data file is processed separately. The instantaneous observations which have occasional spikes due to both electronic and physical noise were checked in each file for spikes. If some spikes were detected, they were removed and those erroneous data points were replaced with the interpolated value of that observation. In all the available data files, very few files with few spikes were found. An arithmetic mean of 18,000 data samples of each variable is estimated and used to estimate the fluctuating component of that variable as shown in equations $1(\mathrm{a}-\mathrm{f})$. The WPL correction for density effects due to heat and water vapour transfer (Webb et al. 1980) and data quality control test for steady state and integral turbulence characteristics (Foken and Wichura 1996) have been applied. Since we used the open-path $\mathrm{CO}_{2} / \mathrm{H}_{2} \mathrm{O}$ gas analyzer (Model LI-7500A), the sensor response time delay is ignored.

\section{Results and discussion}

\subsection{Diurnal variation of $\mathrm{CO}_{2} \mathrm{flux}$}

The diurnal variations of $\mathrm{CO}_{2}$ flux vary from rural site to urban site. Over the rural site (free from anthropogenic activities), only one maxima in the $\mathrm{CO}_{2}$ observations, connected with diurnal convection is observed, but over an urban site, more maximas (Coutts et al. 2007) connected with vehicular traffic load, domestic activities, cultural festivals, etc., are observed. Opposite to the observation over rural site, $\mathrm{CO}_{2}$ flux could be positive during daytime (Coutts et al. 2007; Pawlak et al. 2011) over an urban area because of insufficient photosynthesis. Figure 3 shows the diurnal variation of (a) $\mathrm{CO}_{2}$ flux, (b) $\mathrm{H}_{2} \mathrm{O}$ flux, (c) $\mathrm{CO}_{2}$ concentration, (d) $\mathrm{H}_{2} \mathrm{O}$ concentration, (e) sensible and latent heat flux and (f) friction velocity observed on September 24, 2011. A pronounced diurnal variation is seen in all the above parameters. The $\mathrm{CO}_{2}$ flux was observed to be negative (uptake) during daytime and positive in the night-time. The maximum $\mathrm{CO}_{2}$ uptake was observed in the noon hours (figure $3 \mathrm{a}$ ) when the intensity of solar radiation was high. Being a rural site, we observed one diurnal maxima (peak) at 10-12 hrs IST in $\mathrm{CO}_{2}$ flux. During daytime, Lohou et al. (2010) observed the $\mathrm{CO}_{2}$ flux in range of -6 to $-20 \mu \mathrm{mol} \mathrm{m}{ }^{-2} \mathrm{~s}^{-1}$ in rainy season (May-September) over the tropical Nangatchori site in northern Benin, located in a Sudanian-Guinean vegetation-type area, surrounded by woodland, crops and fallow. The $\mathrm{CO}_{2}$ 

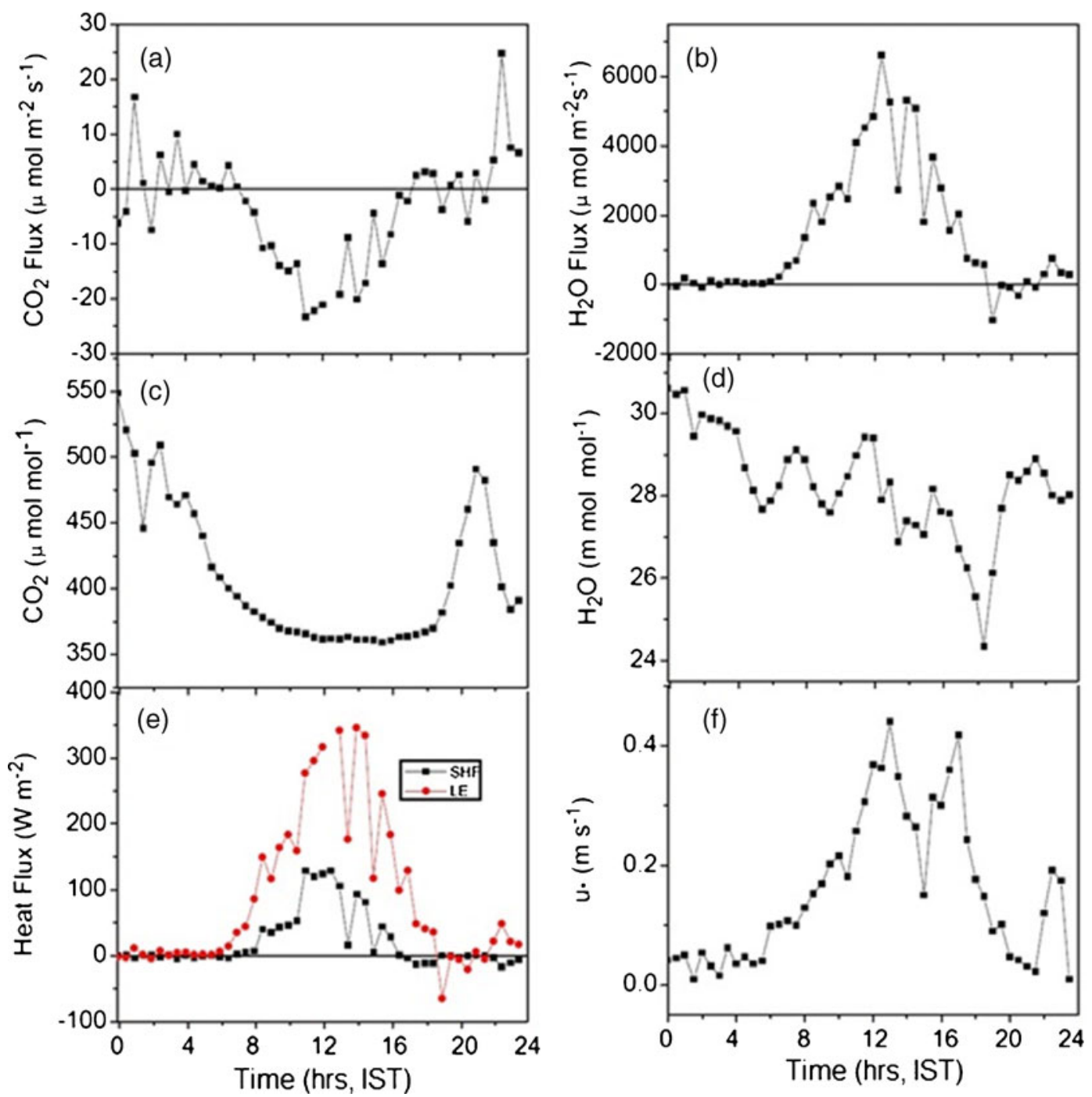

Figure 3. Diurnal variation of (a) $\mathrm{CO}_{2}$ flux, (b) $\mathrm{H}_{2} \mathrm{O}$ flux, (c) $\mathrm{CO}_{2}$ concentration, (d) $\mathrm{H}_{2} \mathrm{O}$ concentration, (e) sensible and latent heat flux and (f) friction velocity observed on September 24, 2011.

flux observed by Lohou et al. (2010) corroborated with the result presented in this study. The water vapour flux (figure $3 \mathrm{~b}$ ) showed maxima at noon (1200 hrs, IST).

As seen in figure $3(\mathrm{c})$, a minimum $\mathrm{CO}_{2}$ concentration was observed in the afternoon hours and maximum at around midnight (2330-0100 hrs, IST). It is evident that the atmospheric concentrations of trace gases within the boundary layer are controlled to a large extent by intensity of vertical mixing processes (Emeis 2008). During daytime, when strong thermal convection prevails, $\mathrm{CO}_{2}$ emitted from the surface is diluted in a large volume of well-mixed boundary layer, hence the low $\mathrm{CO}_{2}$ concentration in the noon hours. After the sunset, vertical mixing is reduced. The diurnal variation of $\mathrm{CO}_{2}$ reported in this study is in agreement with the results of Reid and Steyn (1997). During the periods of low wind speed, when advection is small, this leads to accumulation of
$\mathrm{CO}_{2}$ emitted from the surface and its concentrations within the boundary layer start to increase. Hence, the $\mathrm{CO}_{2}$ concentration was increased in the night-time as seen in figure $3(\mathrm{c})$. Thus, a $\mathrm{CO}_{2}$ uptake flux in the noon hours was greater due to the biogenic processes whereas minimum $\mathrm{CO}_{2}$ concentration was due to the intense convective instability, biospheric photosynthesis and greater boundary layer height. In low friction velocity $(0-$ $0.10 \mathrm{~ms}^{-1}$ ), the $\mathrm{CO}_{2}$ flux was ranging from -5.0 to $+7.0 \mu \mathrm{mol} \mathrm{m} \mathrm{m}^{-2} \mathrm{~s}^{-1}$. Two peaks in the $\mathrm{CO}_{2}$ concentration, one at $2100 \mathrm{hrs}$ and another at 0000 hrs (figure 3c) were observed. Such peaks were not observed on all the days. Sometimes, besides midnight peak value, another peak was noticed at 1000 hrs. Such abnormal peaks could be due to emission of $\mathrm{CO}_{2}$ by a train passing at that time. The peak shown in figure 3(c) is well pronounced because of the absence of solar radiation and accumulation of $\mathrm{CO}_{2}$ in stable boundary layer. 


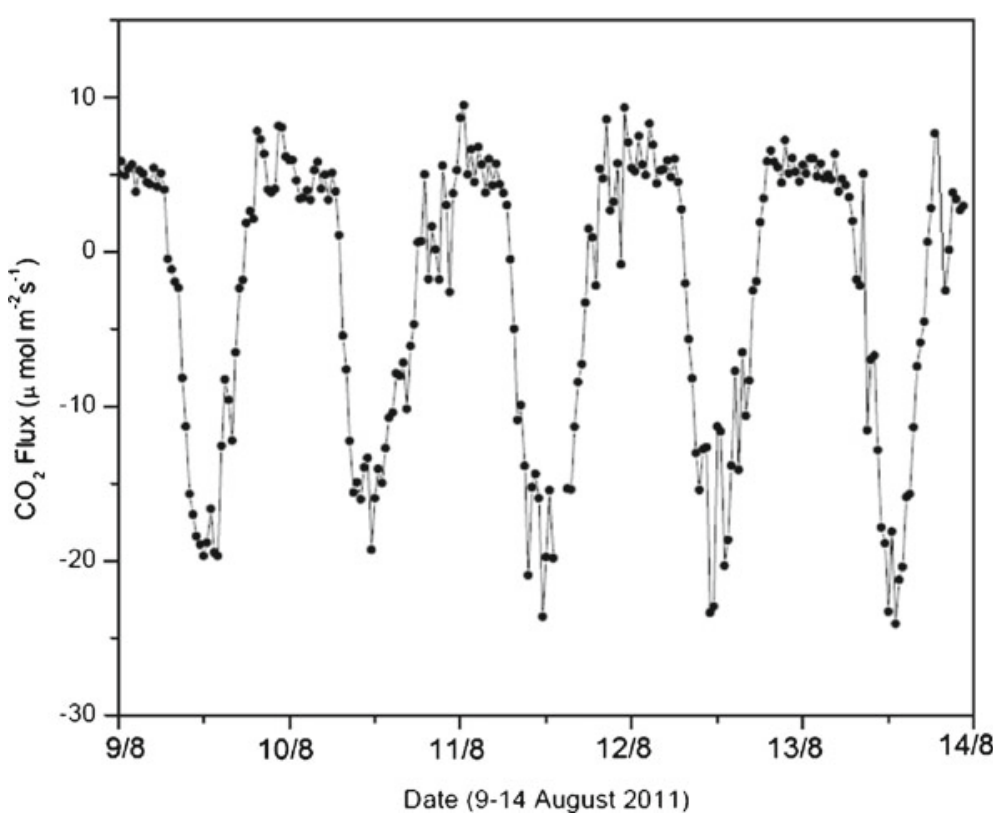

Figure 4. Diurnal variation of $\mathrm{CO}_{2}$ flux during 9-14 August, 2011 over Mahabubnagar.

However, during noon time, $\mathrm{CO}_{2}$ concentration is dispersing $\mathrm{CO}_{2}$ in a large volume of unstable boundary layer. The peak observed at midnight is an undisturbed diurnal maxima which is observed on all days. The water vapour concentration was greater in the midnight hours (figure $3 \mathrm{~d}$ ). The diurnal variation in sensible and latent heat flux (figure 3e) showed greater magnitude in the noon hours due to an intense convective instability. The water vapour flux (figure $3 \mathrm{~b}$ ) and friction velocity (figure 3f) were also greater at this time.

Figure 4 shows diurnal variation of $\mathrm{CO}_{2}$ flux observed during the non-rainy period of 9-14 August, 2011 over the observational site. The $\mathrm{CO}_{2}$ flux was in the range of -24.1 to $9.5 \mu \mathrm{mol} \mathrm{m} \mathrm{m}^{-2} \mathrm{~s}^{-1}$. Observed night-time flux in this study is comparable with the results by Lee and $\mathrm{Hu}$ (2002) over the mid-latitudinal region of mixed forest on nonflat terrain. They observed positive flux of $\mathrm{CO}_{2}$ $\left(>23 \mu \mathrm{mol} \mathrm{m}{ }^{-2} \mathrm{~s}^{-1}\right)$ frequently at night hours. Kidston et al. (2010) observed the $\mathrm{CO}_{2}$ flux in the range of -6 to $4 \mu \mathrm{mol} \mathrm{m} \mathrm{m}^{-2} \mathrm{~s}^{-1}$ in the summer season over Jack Pine forest of Canada. It is also evident that the subtropical plantations are the large carbon sinks (Chen et al. 2011). A mean of half hourly $\mathrm{CO}_{2}$ flux over a period of whole monsoon (July-September) period was observed to be $-3.55 \pm 9.48 \mu \mathrm{mol} \mathrm{m}{ }^{-2} \mathrm{~s}^{-1}$, which indicated that the region of Mahabubnagar is not a source of $\mathrm{CO}_{2}$, but it is a sink region. The seasonal mean of $\mathrm{CO}_{2}$ concentration was observed to be $385.90 \pm$ $18.87 \mathrm{ppm}$. The median for July to September (monsoon season) of $\mathrm{CO}_{2}$ concentration and $\mathrm{CO}_{2}$ flux was observed to be $382.52 \mathrm{ppm}$ and $-3.10 \mu \mathrm{mol} \mathrm{m} \mathrm{m}^{-2} \mathrm{~s}^{-1}$, respectively. An analysis also

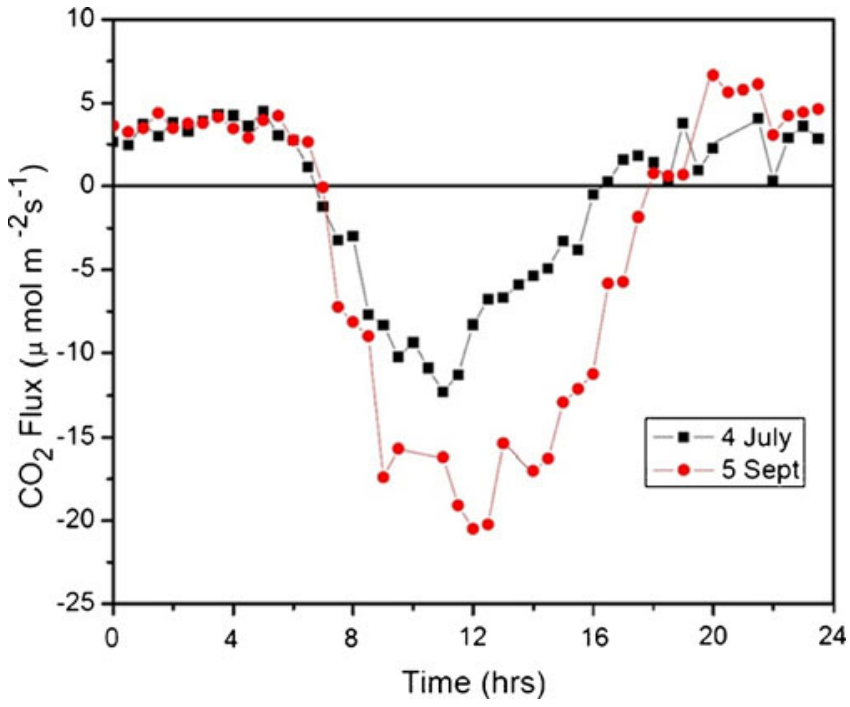

Figure 5. Diurnal variation of $\mathrm{CO}_{2}$ flux on 4 th July and 5 th September, 2011.

showed that there was no change in the $\mathrm{CO}_{2}$ concentration on weekend days due to absence of heavy vehicular traffic.

\subsection{Effect of soil moisture on diurnal variation of $\mathrm{CO}_{2}$ flux}

It is evident that the vegetation is the net storage/sink of $\mathrm{CO}_{2}$. The plants use $\mathrm{CO}_{2}$ in the photosynthesis process. Figure 5 shows the $30 \mathrm{~min}$. $\mathrm{CO}_{2}$ flux observed on 4th July and 5th September, 2011. The southwest monsoon arrived over the experimental site on 11 June. The observations 

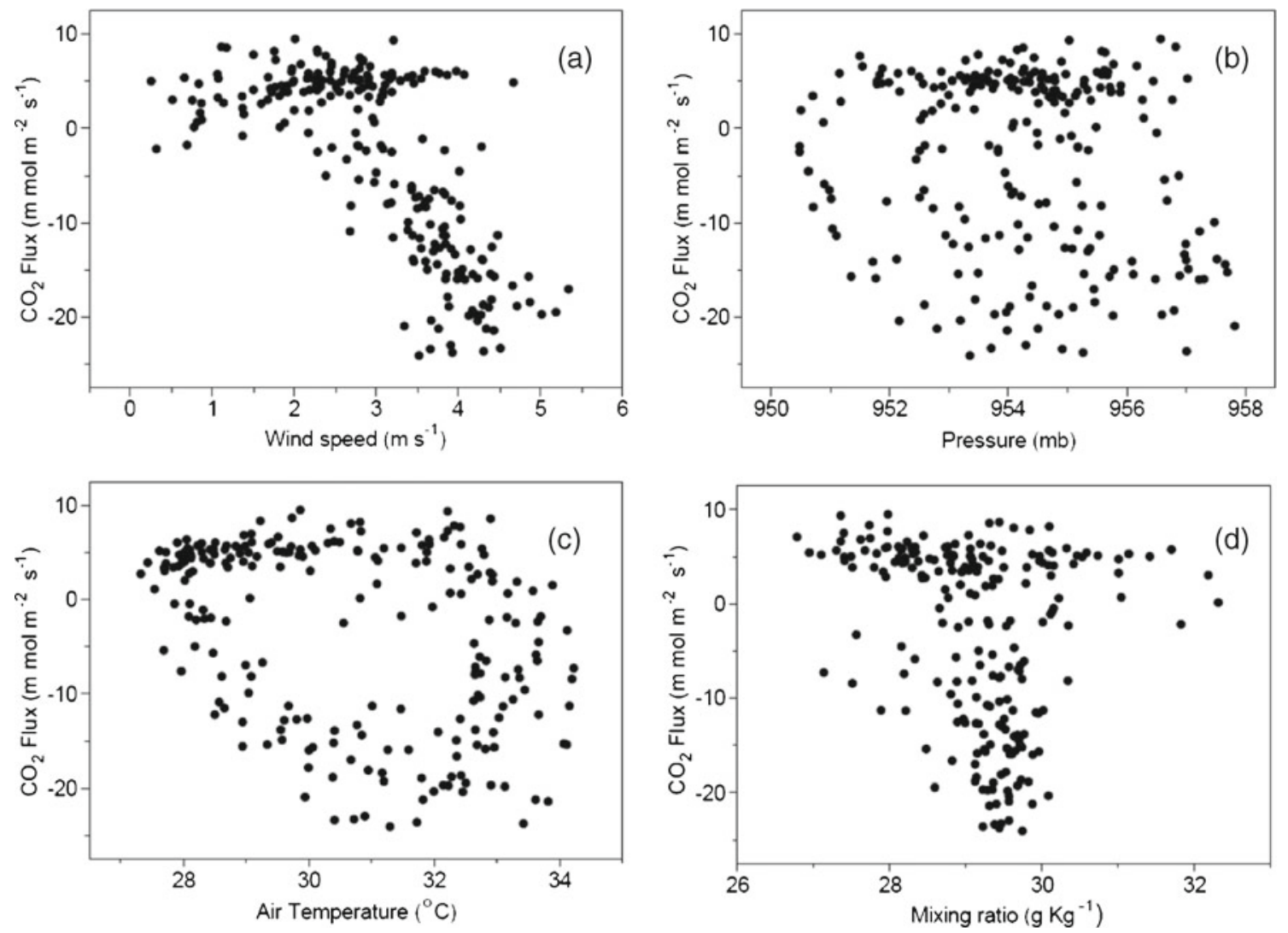

Figure 6. Dependency of $\mathrm{CO}_{2}$ flux on (a) wind speed, (b) surface air pressure, (c) air temperature and (d) mixing ratio.

were started in the first week of July. The soil moisture was considerably low in the first week of July than that of in the month of September. Plants are more developed in September compared to July. In the second part of night (10 PM to $7 \mathrm{AM}$ ), the $\mathrm{CO}_{2}$ flux was nearly constant (figure 5). After sunrise, the $\mathrm{CO}_{2}$ flux was more in September than in July. During daytime, the maximum uptake of $\mathrm{CO}_{2}$ was $-12.5 \mu \mathrm{mol} \mathrm{m} \mathrm{m}^{-2} \mathrm{~s}^{-1}$ in July which increased to $-21 \mu \mathrm{mol} \mathrm{m}{ }^{-2} \mathrm{~s}^{-1}$ in the month of September. The greater $\mathrm{CO}_{2}$ flux in the month of September was attributed to the enhanced photosynthesis process with availability of greater soil moisture and well developed plants than in the month of July.

\section{$4.3 \mathrm{CO}_{2}$ fluxes and meteorological parameters}

Figure $6(\mathrm{a}-\mathrm{d})$ shows the observed variation of $\mathrm{CO}_{2}$ flux with wind speed, air pressure, air temperature and mixing ratio, respectively for the period of 9-14 August, 2011. It is interesting to note here that, a $\mathrm{CO}_{2}$ flux showed relation with wind speed, but not with air temperature, mixing ratio (humidity) or air pressure. For the wind speed $<2 \mathrm{~ms}^{-1}$, $\mathrm{CO}_{2}$ flux was positive with less variation. In this case, with increase of wind speed (and net radiation, sensible and latent heat flux), increase of $\mathrm{CO}_{2}$ flux is also observed but it becomes more negative $\left(\mathrm{CO}_{2}\right.$ uptake becomes more intense) as seen in figure $7(\mathrm{a}, \mathrm{b}$ and $\mathrm{c})$. In the mid-latitudinal region too, Merbold et al. (2011) expressed poor relationship of $\mathrm{CO}_{2}$ flux with air temperature, wind speed and air pressure. Contini et al. (2012) too expressed poor correlation between $\mathrm{CO}_{2}$ flux and meteorological parameters due to the influence of the biogenic cycle over the town of Lecce (Italy). The linear relationship of $\mathrm{CO}_{2}$ flux with sensible heat flux $(\mathrm{H})$, latent heat flux $(\mathrm{LE})$ and net radiation $(\mathrm{Rn})$ is established as $\mathrm{FCO}_{2}=-0.25 * \mathrm{H}-0.35, \mathrm{FCO}_{2}=$ $-0.06 * \mathrm{LE}+5.90$ and $\mathrm{FCO}_{2}=-0.05 * \mathrm{Rn}+2.73$, respectively. The relation between $\mathrm{FCO}_{2}$ and $\mathrm{H}$ and LE fluxes is mainly a result of diurnal rhythm of turbulence. This relationship is site specific and valid for the wind speed less than $5 \mathrm{~ms}^{-1}$ with $\mathrm{CO}_{2}$ concentration in the range of 366-452 $\mathrm{mol} \mathrm{mol}^{-1}$. The response from the fluxes of $\mathrm{CO}_{2}$, sensible and latent heat to the precipitation $(113 \mathrm{~mm})$ that occurred over the study area on 21 August (day number 233, see figure 2) have been examined. The sensible and latent heat flux were also increased by $\sim 35$ and $\sim 136 \mathrm{~W} \mathrm{~m}^{-2}$, respectively after passing the rainfall event (see figure 8a). Due to intense rainfall on this day, it is interesting to note that, on the next day (day number 234, 22 August), the daytime $\mathrm{CO}_{2}$ uptake (negative $\mathrm{CO}_{2}$ flux) at peak 

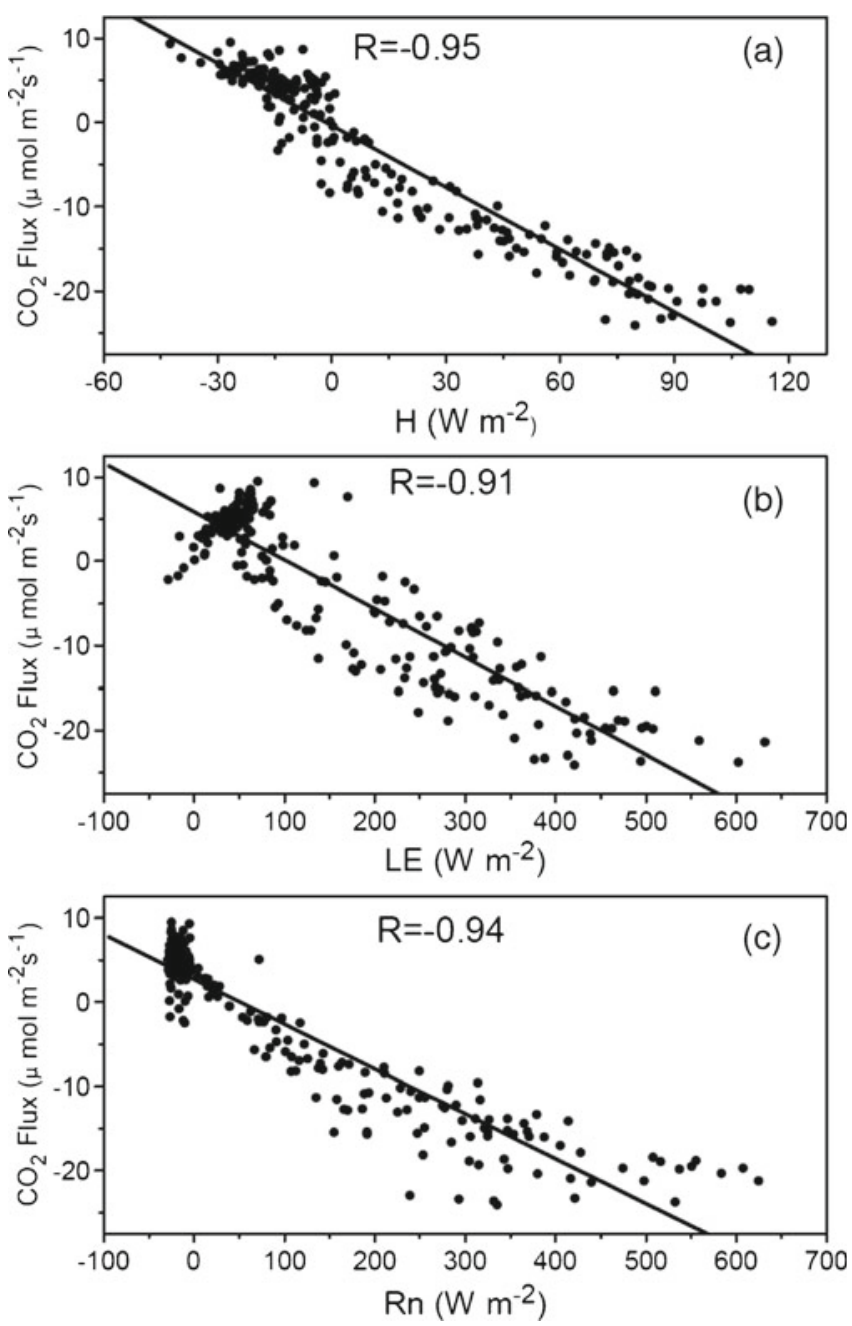

Figure 7. Dependency of $\mathrm{CO}_{2}$ flux on (a) sensible heat flux, (b) latent heat flux and (c) net radiation.

hour increased by $\sim-6.8 \mu \mathrm{mol} \mathrm{m} \mathrm{m}^{-2} \mathrm{~s}^{-1}$ as seen in figure $8(\mathrm{~b})$. The change in air temperature due to rain episode is given in figure 8(c). Following the precipitation event, an increase in $\mathrm{CO}_{2}$ uptake indicates that the regions with high soil moisture can uptake greater amount of $\mathrm{CO}_{2}$ and utilize efficiently in the photosynthesis process. Otherwise, in few studies from the mid-latitudinal region (Barr et al. 2012), in response to hurricane (disturbance), more efficient transport of $\mathrm{CO}_{2}$ from the surface, and decrease in sensible heat flux was observed. In the present study, the significant increase of latent heat flux was observed. A study (Brummer et al. 2008) over the tropical region, i.e., south-west of Burkina Faso, showed the net $\mathrm{CO}_{2}$ uptake in the monsoon season which corroborates with our findings. From the above findings and discussions, it is appropriate to conclude that the rural part of the Indian subcontinent, particularly during monsoon season, can be a $\mathrm{CO}_{2}$ sink region.

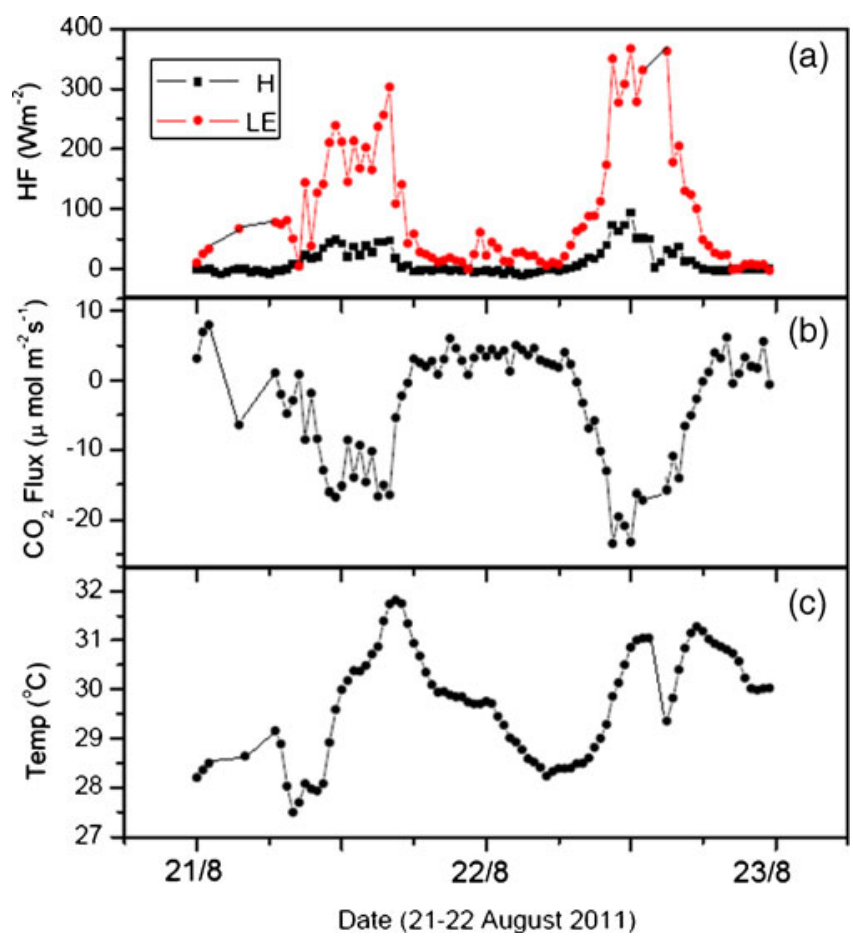

Figure 8. Diurnal variation of fluxes of (a) sensible and latent heat, (b) $\mathrm{CO}_{2}$ flux and (c) air temperature observed on 21-22 August, 2011.

\section{Conclusions}

$\mathrm{CO}_{2}, \mathrm{H}_{2} \mathrm{O}$ concentrations and their fluxes in the rural area of south-east India site (Mahabubnagar) were analysed using the eddy-covariance technique. The result showed that the measurement site, which is rural, is a net sink of $\mathrm{CO}_{2}$ in the monsoon season. The measured fluxes showed a clear daily pattern correlated with diurnal stability. The effect of the biogenic cycle was clearly visible on $\mathrm{CO}_{2}$ fluxes. The $\mathrm{CO}_{2}$ flux showed conclusive relationship with wind speed, net radiation, sensible and latent heat fluxes. However, there was no clear relation of the $\mathrm{CO}_{2}$ flux with air temperature, water vapour mixing ratio and air pressure as a single parameter. The $\mathrm{CO}_{2}$ uptake was low at the beginning of monsoon season, but it enhanced towards the end of the season mainly because of enhanced photosynthesis processes with the availability of greater soil moisture.

\section{Acknowledgements}

The authors express their gratitude to Prof B N Goswami, Director, Indian Institute of Tropical Meteorology, Pune for inspiration. The CAIPEEXIGOC program was fully funded by the Ministry of Earth Sciences, Govt. of India. The team members of the CAIPEEX-IGOC are acknowledged for their 
help in collection of valuable observations used in the analysis.

\section{References}

Artuso F, Chamard P, Piacentino S, Sferlazzo D M, De Silvestri L, di Sarra A, Meloni D and Monteleone F 2009 Influence of transport and trends in atmospheric $\mathrm{CO}_{2}$ at Lampedusa; Atmos. Environ. 43 3044-3051.

Barr J G, Engel V, Smith T J and Fuentes J D 2012 Hurricane disturbance and recovery of energy balance, $\mathrm{CO}_{2}$ fluxes and canopy structure in a mangrove forest of the Florida Everglades; Agric. Forest Meteorol. 153 54-66.

Brummer C, Falk U, Papen H, Szarzynski J, Wassmann R and Bruggemann N 2008 Diurnal, seasonal, and interannual variation in carbon dioxide and energy exchange in shrub savanna in Burkina Faso (West Africa); J. Geophys. Res. 113 G02030, doi: 10.1029/2007JG000583.

Casso-Torralba P, Vilà-Guerau de Arellano J, Bosveld F, Soler M, Vermeulen A, Werner C and Moors E 2008 Diurnal and vertical variability of the sensible heat and carbon dioxide budgets in the atmospheric surface layer; J. Geophys. Res. 113 D12119, doi: 10.1029/2007JD009583.

Chen D, Zhang C, Wu J, Zhou L, Lin Y and Fu S 2011 Subtropical plantations are large carbon sinks: Evidence from two monoculture plantations in South China; Agric. Forest Meteorol. 151 1214-1225.

Contini D, Donateo A, Elefante C and Grasso F M 2012 Analysis of particles and carbon dioxide concentrations and fluxes in an urban area: Correlation with traffic rate and local micrometeorology; Atmos. Environ. 46 25-35.

Coutts A M, Beringer J and Tapper N J 2007 Characteristics influencing the variability of urban $\mathrm{CO}_{2}$ fluxes in Melbourne, Australia; Atmos. Environ. 41 51-62.

Dharmaraj T, Patil M N, Waghmare R T and Raj P E 2012 Carbon dioxide and water vapour characteristics on the west coast of Arabian Sea during Indian summer monsoon; J. Earth Syst. Sci. 121(4) 903-910.

Emeis S 2008 Examples for the determination of turbulent (subsynoptic) fluxes with inverse methods; Meteorol. Z. 17 3-11.

Foken T and Wichura B 1996 Tools for quality assessment of surface based flux measurements; Agric. Forest Meteorol. 78 83-105.

Gibert F, Schmidt M, Cuesta J, Ciais P, Ramonet M, Xueref I, Larmanou E and Flamant P H 2007 Retrieval of average $\mathrm{CO}_{2}$ fluxes by combining in situ $\mathrm{CO}_{2}$ measurements and backscatter lidar information; J. Geophys. Res. 112 D10301, doi: 10.1029/2006JD008190.
IPCC 2007 Climate Change 2007 - The Physical Science Basis; Contribution of Working Group I to the Fourth Assessment Report of the Intergovernmental Panel on Climate Change; Cambridge University Press, Cambridge, UK, 996p.

Keeling C D, Whorf T P, Wahlen M and van der Plichtt J 1995 Interannual extremes in the rate of rise of atmospheric carbon dioxide since 1980; Nature 375 666-670.

Kidston J, Brümmer C, Black T A, Morgenstern K, Nesic Z, McCaughey J H and Barr A G 2010 Energy balance closure using eddy covariance above two different land surfaces and implications for $\mathrm{CO}_{2}$ flux measurements; Bound.-Layer Meteorol. 136 193-218.

Lee X and Hu X 2002 Forest-air fluxes of carbon, water and energy over non-flat terrain; Bound.-Layer Meteorol. 103 277-301.

Lee X, Massman W and Law B 2004 Handbook of Micrometeorology: A Guide for Surface Flux Measurement and Analysis; Kluwer Academic Publishers, pp. 60-61.

Lohou F, Said F, Lothon M, Durand P and Serca D 2010 Impact of boundary-layer processes on near-surface turbulence within the West African Monsoon; Bound.-Layer Meteorol. 136 1-23.

Merbold L, Rogiers N and Eugste W 2011 Winter $\mathrm{CO}_{2}$ fluxes in a sub-alpine grassland in relation to snow cover, radiation and temperature; Biogeochemistry, doi: 10.1007/s10533-011-9647-2.

Pawlak W, Fortuniak K and Siedlecki M 2011 Carbon dioxide flux in the centre of Łódź, Poland - analysis of a 2-year eddy covariance measurement data set; Int. J. Climatol. 31 232-243.

Reid K H and Steyn D G 1997 Diurnal variations of boundary-layer carbon dioxide in a coastal city - Observations and comparison with model results; Atmos. Environ. 31 3101-3114.

Song T and Wang Y 2012 Carbon dioxide fluxes from an urban area in Beijing; Atmos. Res. 106 139-149.

van der Laan S, Neubert R E M and Mejier H A J 2009 Methane and nitrous oxide emissions in The Netherlands: Ambient measurements support the national inventories; Atmos. Chem. Phys. 9(24) 9369-9379.

Webb E K, Pearman G I and Leuning R 1980 Correction of the flux measurements for density effects due to heat and water vapour transfer; Quart. J. Roy. Meteorol. Soc. 106 85-100.

Worthy D E, Chan E, Ishizawa M, Chan D, Poss C, Dlugokencky E J, Maksyutov S and Levin I 2009 Decreasing anthropogenic methane emissions in Europe and Siberia inferred from continuous carbon dioxide and methane observations at Alert, Canada; J. Geophys. Res. 114 D10301, doi: 10.1029/2008JD011239. 